\title{
Combined Effect of Organic Manures and Inorganic Fertilizers on the Growth and Yield of Hybrid Rice (Palethwe-1)
}

\author{
Kyi Moe ${ }^{1,2^{*}}$, Kumudra Win Mg2*, Kyaw Kyaw Win'2, Takeo Yamakawa ${ }^{3}$ \\ ${ }^{1}$ Plant Nutrition Laboratory, Graduate School of Bioresource and Bioenvironmental Sciences, Faculty of Agriculture, Kyushu \\ University, Fukuoka, Japan \\ ${ }^{2}$ Department of Agronomy, Yezin Agricultural University, Yezin, Myanmar \\ ${ }^{3}$ Plant Nutrition Laboratory, Division of Molecular Biosciences, Department of Biosciences \& Biotechnology, Faculty of \\ Agriculture, Kyushu University, Fukuoka, Japan \\ Email: "kyimoeyau@gmail.com
}

How to cite this paper: Moe, $\mathrm{K} ., \mathrm{Mg}$, K.W., Win, K.K. and Yamakawa, T. (2017) Combined Effect of Organic Manures and Inorganic Fertilizers on the Growth and Yield of Hybrid Rice (Palethwe-1). American Journal of Plant Sciences, 8, 1022-1042. https://doi.org/10.4236/ajps.2017.85068

Received: March 3, 2017

Accepted: April 18, 2017

Published: April 21, 2017

Copyright (C) 2017 by authors and Scientific Research Publishing Inc. This work is licensed under the Creative Commons Attribution International License (CC BY 4.0).

http://creativecommons.org/licenses/by/4.0/

\begin{abstract}
We investigated the effect of combining organic and inorganic fertilizers on the growth and yield of hybrid rice (Palethwe-1) in the dry and wet seasons of 2015. Four quantities of inorganic fertilizer were used in the main plot $[0 \%$, $50 \%, 75 \%$, and $100 \%$ nitrogen, phosphorus, and potassium (NPK)] based on the recommended amounts of $150 \mathrm{~kg} \mathrm{~N} \mathrm{ha}^{-1}, 70 \mathrm{~kg} \mathrm{P}_{2} \mathrm{O}_{5} \mathrm{ha}^{-1}$, and $120 \mathrm{~kg} \mathrm{~K}_{2} \mathrm{O}$ $\mathrm{ha}^{-1}$, while different organic manures were applied to subplots [no organic manure $\left(\mathrm{O}_{0}\right)$, cow manure $\left(\mathrm{O}_{c}\right)$, poultry manure $\left(\mathrm{O}_{\mathrm{p}}\right)$, and vermicompost $\left(\mathrm{O}_{\mathrm{v}}\right)$; all at $\left.5 \mathrm{t} \cdot \mathrm{ha}^{-1}\right]$ as part of a split-plot experimental design with three replicates. In both seasons, significant differences in growth parameters including number of tillers hill ${ }^{-1}$, soil-plant analysis development (SPAD) values, total dry matter, yield, and yield components were observed in plants supplied with different inorganic fertilizers. The $100 \%$ NPK $\left(\mathrm{I}_{100}\right)$ fertilizer produced the maximum yield but similar yields were achieved in plots supplied with $50 \%$ NPK $\left(I_{50}\right)$ and 75\% NPK $\left(I_{75}\right)$. Significant differences in growth and yield parameters were also found in crops supplied with organic manures. Although identical quantities were supplied, $\mathrm{O}_{\mathrm{p}}$ produced the best growth parameters in both seasons including total dry matter, yield, and yield components. $\mathrm{O}_{c}$ also performed well. Combining inorganic and organic fertilizers demonstrated that $\mathrm{I}_{50}$ together with $\mathrm{O}_{\mathrm{p}}\left(5 \mathrm{t} \cdot \mathrm{ha}^{-1}\right)$ provided similar growth, total dry matter, and yield parameters to $\mathrm{I}_{100}$ in both seasons. $\mathrm{O}_{\mathrm{c}}\left(5 \mathrm{t} \cdot \mathrm{ha}^{-1}\right)$ plus $\mathrm{I}_{75}$ also achieved similar yields to $\mathrm{I}_{100}$. This study demonstrates that the combined application of inorganic fertilizers and organic manures has the potential to reduce chemical fertilizer usage without decreasing the yield of hybrid rice, and can enhance the growth, yield, and yield components of Palethwe-1.
\end{abstract}

*Equally contributed to this research. 


\section{Keywords}

Growth Parameter, Inorganic Fertilizers, Organic Manures, Rice, Yield

\section{Introduction}

Rice is a staple food in Asia where approximately $92 \%$ of the world's rice is produced and consumed [1]. It constitutes a significant part of the overall diet for the 53.9 million people of Myanmar and is harvested from 8 million hectares of farmland annually [2].

Recent concerns over food security have resulted in the global adoption of hybrid rice as an alternative to purebred varieties. Hybrid rice is any genealogy of rice produced by crossbreeding different kinds of rice. It typically displays heterosis (hybrid vigor) and when grown under the same conditions as high-yield inbred rice varieties can produce a yield that is up to $30 \%$ greater [3]. High-yield crops that include hybrid rice are an important tool in combating world food shortages. In China, approximately half of the total 30 million hectares used for growing rice contains hybrid rice and this produces 103.5 million tons (17\% of the world's paddy rice production), which is 22.5 million tons of extra paddy every year. This extra production conserves approximately 6 million hectares of land and consequently hybrid rice not only contributes to food security but also plays an important part in protection of the global environment [4].

Myanmar has been developing hybrid rice since 1997 and has made the varieties developed available for domestic consumption [5]. Growing hybrid rice is complex because its agronomic management differs considerably from that of conventional inbred rice varieties in many respects [6]. For example, although the life cycles of hybrid and inbred rice are similar, hybrid rice is more vigorous during its vegetative phase and in particular at the seedling stage. It was recently demonstrated that the increase in yield per unit of nitrogen $(\mathrm{N})$ supplied decreased as the quantity of mineral $\mathrm{N}$ fertilizer applied increased. In addition, excessive use of chemical fertilizers in agriculture has led to a variety of environmental problems and in the future, fertilizers will be a major source of heavy metals and radionuclides accumulating as inorganic pollutants in plants [7].

In Myanmar's central dry zone, farmers have tried to maximize their profits by adopting optimal management practices that include improving the indigenous soil $\mathrm{N}$ content and applying the minimal amount of fertilizer possible without reducing yield. Another potential improvement is the use of organic manures in combination with mineral fertilizers [8] [9]. In the dry zone, cow manure $\left(\mathrm{O}_{c}\right)$ is readily available for hybrid rice cultivation. Bhuiyan [10] indicated that the application $\mathrm{O}_{\mathrm{c}}$ at $5 \mathrm{t} \cdot \mathrm{ha}^{-1} \cdot \mathrm{year}^{-1}$ improved rice productivity and prevented the degradation of soil resources. Poultry manure $\left(\mathrm{O}_{\mathrm{p}}\right)$ is also a good source of organic matter and may improve soil fertility together with supplying the nutrients necessary for enhanced crop production. $\mathrm{O}_{\mathrm{p}}$ is a good source of nutrients and enhances their uptake over a sustained period of time. The addition of organic 
matter can increase the retention of organic and nitrogenous compounds that are slowly being degraded in the soil [11]. Vermicomposts $\left(\mathrm{O}_{\mathrm{v}}\right)$ have also recently become popular as organic supplements for Myanmar farmers and can enhance the growth of cereals that include sorghum and rice [12] [13]. $\mathrm{O}_{\mathrm{v}}$ are the nutrient-rich, microbiologically-active organic residues derived from the degradation of organic waste by earthworms and microorganisms. They consist of a stable, fine peat-like material with a low $\mathrm{C}: \mathrm{N}$ ratio which is highly porous. They also have a high capacity for water retention and contain most nutrients in forms that can be readily absorbed by plants [14]. The capacity for recycling organic residues has become an increasingly important aspect of environmental safety and sustainable agriculture.

Organic methods of agricultural production have become increasingly popular to reflect consumer demand. Organic matter can provide a continuous and steady source of $\mathrm{N}$ for growing plants. However, while it is $\mathrm{N}$ that is most likely to limit growth in irrigated rice systems, $\mathrm{P}$ (phosphorus) and $\mathrm{K}$ (potassium) deficiencies can also reduce rice yield. As a result, there is increasing interest in the potential use of livestock waste in agricultural soils because this would enable organic matter, $\mathrm{N}, \mathrm{P}$, and $\mathrm{K}$ to be recycled. A major advantage of using organic waste from farms as fertilizer is that some of the most critical nutritional elements can be provided at little cost. By contrast, the application of chemical fertilizers is costly and may exacerbate environmental problems. Therefore, utilization of organic manures may enhance efficient nutrient use in rice and reduce the need for chemical fertilizers. As a result, a judicious combination of organic and inorganic nutrient sources can promote sustainable agriculture and ensure high quality food production [15].

Combining organic manures and chemical fertilizers has the potential to provide greater stability in crop production, maintain improvements in soil fertility, and enhance the efficiency of growth and yield generation in hybrid rice (Palethwe-1). Therefore, understanding how combining different quantities or ratios of organic manures and inorganic fertilizers affects the dry matter, growth, and yield of hybrid rice (Palethwe-1) is extremely valuable.

\section{Materials and Methods}

\subsection{Experimental Site}

Two field experiments were conducted in a farm at the Department of Agronomy, Yezin Agricultural University, Yezin, Nay Pyi Taw, Myanmar $\left(19^{\circ} 10^{\prime} \mathrm{N}\right.$, $96^{\circ} 07^{\prime} \mathrm{E}$ ) (Figure 1). The first field experiment (dry season) was performed between January and April 2015 and the second field experiment (wet season) was performed between August and November 2015. The experimental site is located in the central dry zone of Myanmar whereas is vulnerable to drought as compared to other parts of the country. The agricultural lands receive low rainfall, intense heat and degraded soil conditions, affecting social and economic situations of the communities living in the region (Figure 2). The objective was to study the effect of combining different organic manures and inorganic fertilizers on 


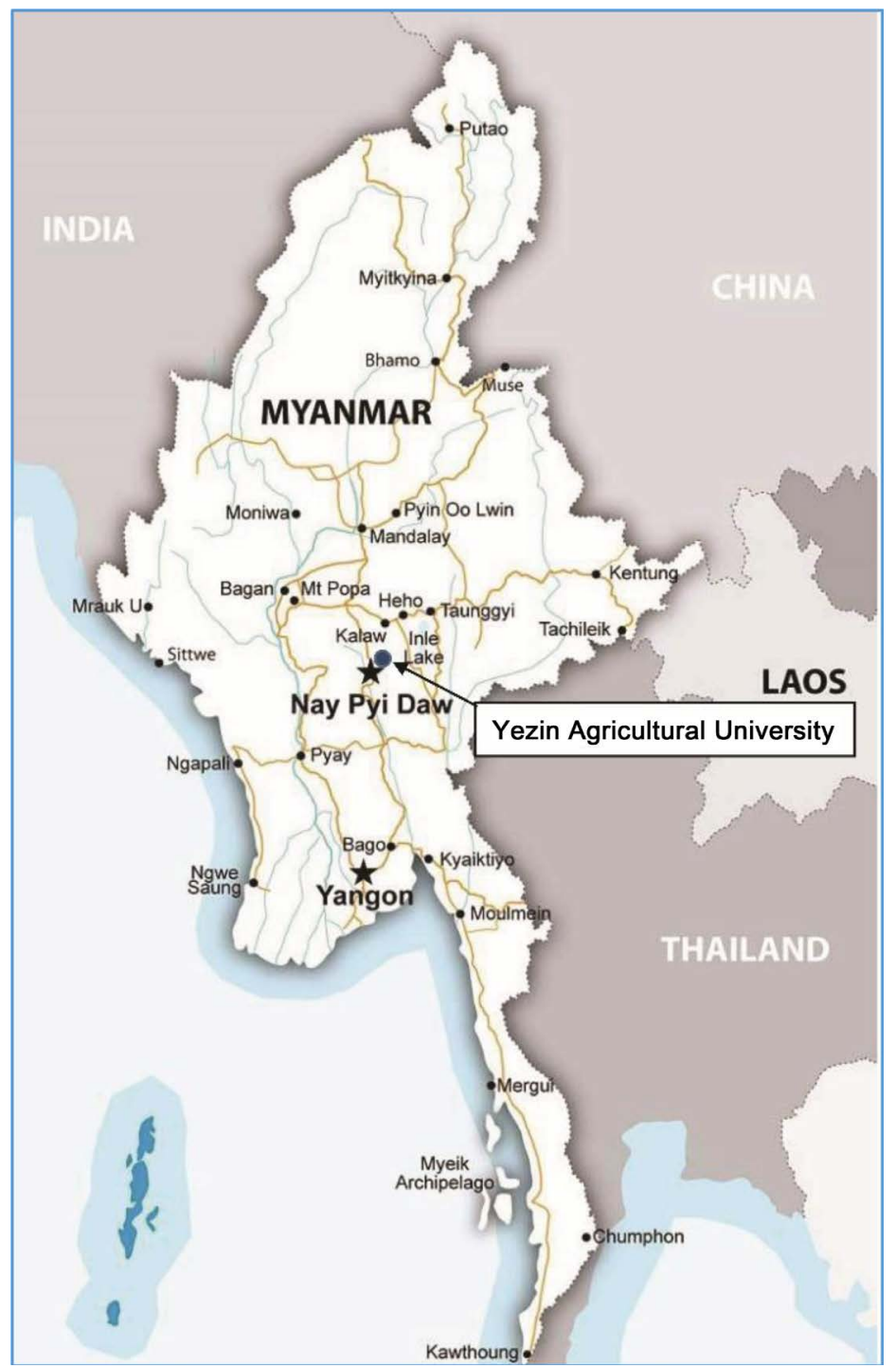

Figure 1. Location of experimental site in Yezin Agricultural University, Nay Pyi Taw.

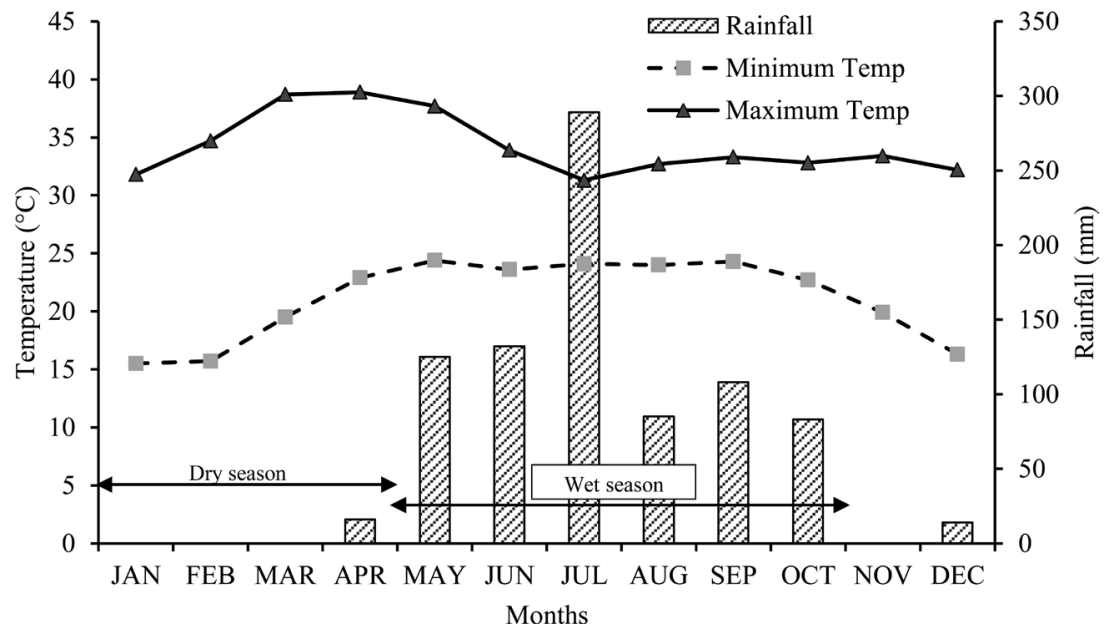

Source: Department of Agricultural Research (DAR), Yezin, Nay Pyi Taw.

Figure 2. Mean monthly rainfall and temperature during the experimental periods in Yezin, Nay Pyi Taw, 2015. 
the growth and yield attributes of hybrid rice (Palethwe-1).

\subsection{Experimental Design and Treatments}

This study was performed using a split-plot experimental design and three replicates. Each experimental plot was $3 \times 5 \mathrm{~m}$ in size. The distance between each replicate and each plot was 2 and $0.5 \mathrm{~m}$, respectively. Inorganic NPK fertilizer $(0 \%, 50 \%, 75 \%$, and $100 \%)$ based on the recommended amounts of $150 \mathrm{~kg} \mathrm{~N}$ $\mathrm{ha}^{-1}, 70 \mathrm{~kg} \mathrm{P}_{2} \mathrm{O}_{5} \mathrm{ha}^{-1}$, and $120 \mathrm{~kg} \mathrm{~K}_{2} \mathrm{O} \mathrm{ha} \mathrm{h}^{-1}$ were supplied to the main plots. Organic manures [no organic manure $\left(\mathrm{O}_{0}\right) ; \mathrm{O}_{c}, \mathrm{O}_{\mathrm{p}}$, and $\mathrm{O}_{v}, 5 \mathrm{t} \cdot \mathrm{ha} \mathrm{a}^{-1}$, each] were supplied to the subplots within each main plot. Each treatment was performed in the same plot position in the two consecutive field experiments.

The land was prepared by plowing and harrowing, and then divided into three areas to form the replicates. Each of the replicate areas was further divided into four main plot areas for each inorganic fertilizer. Each main plot area was divided again into four subplots. Double bunds were constructed to prevent seepage between the adjacent plots. The full amount of each organic manure was applied when the soil was initially prepared. The inorganic fertilizers, which included urea (containing $\mathrm{N}$ ) and muriate of potash (containing $\mathrm{K}_{2} \mathrm{O}$ ) were applied as three equal splits: one third was applied at baseline before the seedlings were transplanted, one third was applied at the active tillering stage, and the remaining third was applied at the panicle initiation stage. The full amount of triple superphosphate (containing $\mathrm{P}_{2} \mathrm{O}_{5}$ ) was applied at baseline.

\subsection{Soil Sampling and Analysis}

Before performing the field experiments, initial soil samples were collected using a soil sampling tube ( $5 \mathrm{~cm}$ in diameter) from eight locations in the experimental field at depths of 0 to $15 \mathrm{~cm}$. These soil samples were air dried at room temperature, crushed by hand, and passed through a $2-\mathrm{mm}$ mesh sieve. The air dried soil samples were then analyzed to establish their physical and chemical properties.

The hydrated soil $\mathrm{pH}$ (1:5, soil:water) in mass ratio was measured with an $\mathrm{F}$ $51 \mathrm{pH}$ meter (Horiba Ltd., Kyoto, Japan) using the 4A1-1:5 soil water suspension method [16]. The available soil $\mathrm{N}\left(\mathrm{mg} \cdot \mathrm{kg}^{-1}\right)$ was extracted using the alkaline permanganate method [17]. Available P $\left(\mathrm{mg} \cdot \mathrm{kg}^{-1}\right)$ was analyzed by $9 \mathrm{C}-\mathrm{Olsen}$ 's P-malachite green method [18] using a UV-Vis spectrophotometer PD-303 (Apel Ltd., Saitama, Japan). The available soil K (mg. $\mathrm{kg}^{-1}$ ) was measured using the $1 \mathrm{~N}$ ammonium acetate extraction method [19] and analyzed using an AA-6200 atomic absorption flame emission spectrophotometer (Shimadzu Corp., Kyoto, Japan). Organic matter (\%) was measured using Tyurin's method [20]. Cation exchange capacity (CEC) was determined using the Leaching method [21]. All soil samples were analyzed at the Department of Agricultural Research (DAR) Yezin, Nay Pyi Taw.

\subsection{Organic Manure Analyses}

The nutrient contents of $\mathrm{O}_{c}, \mathrm{O}_{\mathrm{p}}$, and $\mathrm{O}_{\mathrm{v}}$ were measured using a temperature 
controlled oven and analyzed gravimetrically [22]. The total $\mathrm{N}$ content was analyzed by Kjeldahl's method [23] and measured using Kjeldahl's digestion method and a Vapodest 20 s distillation unit (Gerhardt, Apparate GmbH \& Co. KG, Germany). The total $\mathrm{P}$ was determined using the vanado-molybdate phosphoric acid method [24] and a 6305 UV-VIS spectrophotometer (Jenway, Stone, UK). The total $\mathrm{K}$ was analyzed by the wet digestion method of Stevenson and de Langen [25] using a novAA 400 atomic absorption spectrophotometer (Analytik Jena AG, Jena, Germany). Total S was determined using the turbidimetric method [26] and a 6305 UV-VIS spectrophotometer (Jenway). Organic carbon was measured by the loss on ignition method [27] using a temperature controlled oven and a muffle furnace. The chemical composition of organic manures (Table 1) was also analyzed at the DAR.

\subsection{Crop Management}

Hybrid rice (Oryza sativa L.) variety Palethwe-1 (Myanmar hybrid rice) was cultivated for all field experiments. Seeds were obtained from the Yezin Agricultural University farm, soaked in water for $24 \mathrm{~h}$ and then incubated at $25^{\circ} \mathrm{C}$ for 48 h. Once they had sprouted, the seedlings were sown on a prepared seed bed according to the wet bed method described by the IRRI (International Rice Research Institute). Subsequently, the water level was gradually increased to accommodate seedling height. Two 23-day-old seedlings were transplanted to each hill, with hills spaced $20 \times 20 \mathrm{~cm}$ apart. Throughout the growing season, standard agricultural practices were used to perform irrigation, and insect, disease, and weed control. In both seasons, plants were harvested when the crops reached maturity, approximately $92 \mathrm{~d}$ after transplanting (DAT).

\subsection{Plant Growth Characteristics}

Five hills from each plot were used to determine plant height $(\mathrm{cm})$, number of tillers hill ${ }^{-1}$, and soil-plant analysis development (SPAD) values. These plant growth characteristics were measured at two-week intervals from $10 \mathrm{DAT}$ to $50 \%$ flowering. SPAD values were measured using a SPAD-502 chlorophyll meter (Konica Minolta Inc., Osaka, Japan). The uppermost fully expanded leaf was used to measure the SPAD value before the panicle initiation stage and the flag leaf was used thereafter.

Table 1. Chemical compositions of different organic manures for field experiments.

\begin{tabular}{|c|c|c|c|c|c|c|c|}
\hline \multirow{2}{*}{ No. } & \multirow{2}{*}{ Sample } & \multirow{2}{*}{ Moisture (\%) } & \multirow{2}{*}{ Organic carbon (\%) } & \multicolumn{4}{|c|}{ Total \% (oven dry basic) } \\
\hline & & & & $\mathrm{N}$ & $\mathrm{P}_{2} \mathrm{O}_{5}$ & $\mathrm{~K}_{2} \mathrm{O}$ & $\mathrm{S}$ \\
\hline 1. & Cow manure & 18.54 & 13.39 & 1.05 & 1.99 & 2.34 & 0.59 \\
\hline 2. & Poultry manure & 33.03 & 24.73 & 2.83 & 4.90 & 4.67 & 0.53 \\
\hline 3. & Vermicompost & 28.10 & 13.91 & 1.29 & 0.42 & 0.70 & 0.28 \\
\hline
\end{tabular}

Source: Soil and Plant Analysis Laboratory, Soil Science Section, Soil Science, Water Utilization and Agricultural Engineering Division, Department of Agricultural Research (DAR). 


\subsection{Plant Sampling and Determination of Total Dry Matter, Yield, and Yield Components}

At the active tillering stage, panicle initiation, and flowering, two hills from each plot were cut ( $2-3 \mathrm{~cm}$ above the ground) and used as destructive samples. These samples were oven-dried at $70^{\circ} \mathrm{C}$ for $48 \mathrm{~h}$ and weighed immediately. The dry matter accumulation values were expressed as tons per hectare $\left(\mathrm{t} \cdot \mathrm{ha}^{-1}\right)$.

At harvest time, five hills were used to measure growth characteristics in each plot. These were harvested to determine the total dry matter $\left(\mathrm{t} \cdot \mathrm{ha}^{-1}\right)$ and yield components [(number of panicles hill ${ }^{-1}$, number of spikelets panicle ${ }^{-1}$, filled grain (\%), thousand grain weight $(\mathrm{g})$, and panicle length $(\mathrm{cm})]$. Grain yield $\left(\mathrm{t} \cdot \mathrm{ha}^{-1}\right)$ was measured using the harvest area $\left(5 \mathrm{~m}^{2}\right)$ of each plot. The harvest index was calculated as the ratio of economic yield (seed weight) to biological yield (total dry matter weight) [28].

\subsection{Statistical Analysis}

The data were summarized and subjected to an analysis of variance (ANOVA). The mean values of treatments were compared using Tukey's honestly significant difference (HSD) test at a 5\% probability level using Statistix software (ver. 8.0; Analytical Software, Tallahassee, FL, USA).

\section{Results}

\subsection{Soil Analysis}

Table 2 summarizes the physicochemical properties of the soil surface $(0-15$ $\mathrm{cm})$ at the experimental site.

\subsection{Plant Growth Characteristics}

The height of the rice plants was not significantly affected by the different inorganic fertilizer and organic manure treatments throughout either the wet or dry seasons. Rice plants grown using $100 \%$ NPK $\left(I_{100}\right)$ plus organic manures attained

Table 2. Physical and chemical properties of the surface $(0-15 \mathrm{~cm})$ profile of soil at the experimental site.

\begin{tabular}{ccc}
\hline Characteristics & Value & Rating \\
\hline pH $(1: 5$ soil-water $)$ & 6.6 & Neutral \\
Available $\mathrm{N}\left(\mathrm{mg} \cdot \mathrm{kg}^{-1}\right)$ & 73.0 & Medium \\
Available $\mathrm{P}\left(\mathrm{mg} \cdot \mathrm{kg}^{-1}\right)$ & 20.0 & Medium \\
Available $\mathrm{K}\left(\mathrm{mg} \cdot \mathrm{kg}^{-1}\right)$ & 77.0 & Low \\
Organic matter $(\%)$ & 1.8 & Low \\
CEC $\left(\mathrm{cmol}_{(+)} / \mathrm{kg}\right)$ & 8.0 & Low \\
Texture, \% silt, \% sand, \% clay & $19.64,72.57,7.79$ & \\
Soil textural class & Sandy loam & \\
\end{tabular}

Source: Soil and Plant Analysis Laboratory, Soil Science Section, Soil Science, Water Utilization and Agricultural Engineering Division, Department of Agricultural Research (DAR). 
the maximum plant height but did not differ from those grown using $75 \%$ NPK $\left(\mathrm{I}_{75}\right)$ in either season, particularly when these were supplemented with $\mathrm{O}_{\mathrm{p}}$ (Data not shown).

The number of tillers hill ${ }^{-1}$ was not significantly affected by the different inorganic fertilizer treatments in either season (Figure 3). There was no statistically significant difference in the number of tillers generated using $\mathrm{I}_{100}$ compared with 50\% NPK $\left(\mathrm{I}_{50}\right)$ inorganic fertilizer. However, a larger number of tillers were present in rice plants grown using $\mathrm{I}_{100}$ compared with $0 \% \mathrm{NPK}\left(\mathrm{I}_{0}\right)$ fertilizer. The maximum tiller number was produced using $\mathrm{I}_{75} \mathrm{O}_{\mathrm{p}}$ in the dry season $\left(19.22 \mathrm{hill}^{-1}\right)$ and $\mathrm{I}_{100} \mathrm{O}_{\mathrm{p}}$ in the wet season $\left(17.00\right.$ hill $\left.^{-1}\right)$. The $\mathrm{O}_{\mathrm{c}}$ and $\mathrm{O}_{\mathrm{v}}$ treatments did not produce the maximum number of tillers with any inorganic fertilizer. The $\mathrm{O}_{0}$ plots were also unable to produce the maximum number of tillers with any inorganic fertilizer. The number of tillers hill ${ }^{-1}$ produced using $\mathrm{I}_{0} \mathrm{O}_{0}$ was obviously low since no fertilizer was applied. The results from both seasons were similar (Figure 3(a) and Figure 3(b)).

At approximately $24 \mathrm{DAT}$, before the active tillering stage, SPAD values were not significantly affected by any of the inorganic fertilizer treatments but were slightly affected at later stages of development. SPAD values produced by $I_{50}, I_{75}$, and $\mathrm{I}_{100}$ treatments were similar throughout both seasons (Figure 4). The organic manure treatments produced fluctuations in the SPAD values at all growth stages. The $\mathrm{O}_{\mathrm{p}}$ treatments performed particularly well compared with other organic manures, producing higher SPAD values at all developmental stages (Figure 4(a)). The $\mathrm{O}_{\mathrm{c}}$ and $\mathrm{O}_{\mathrm{v}}$ plots had lower SPAD values but these were higher
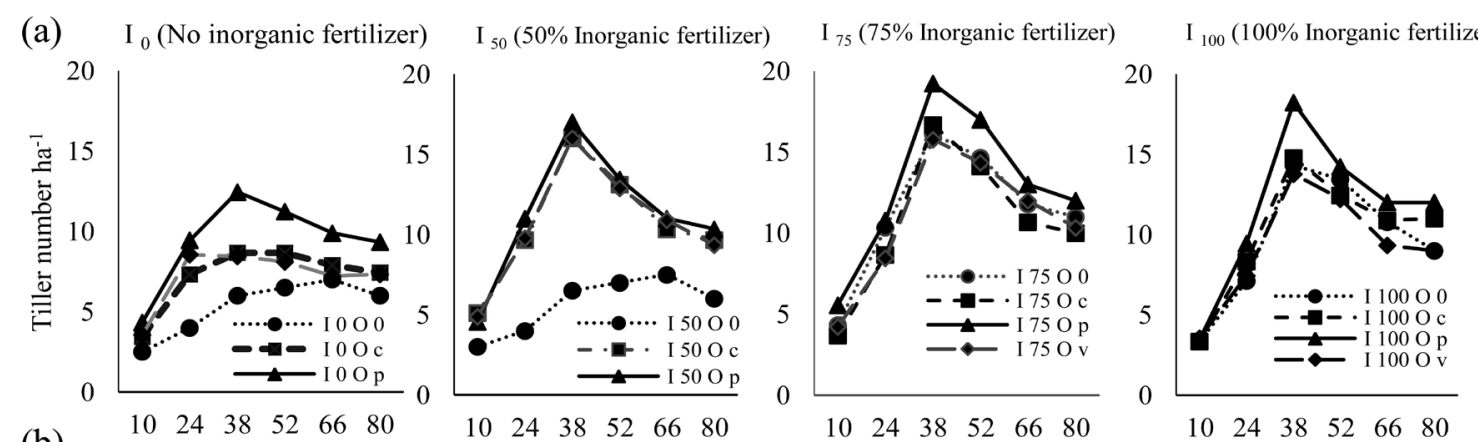

(b)
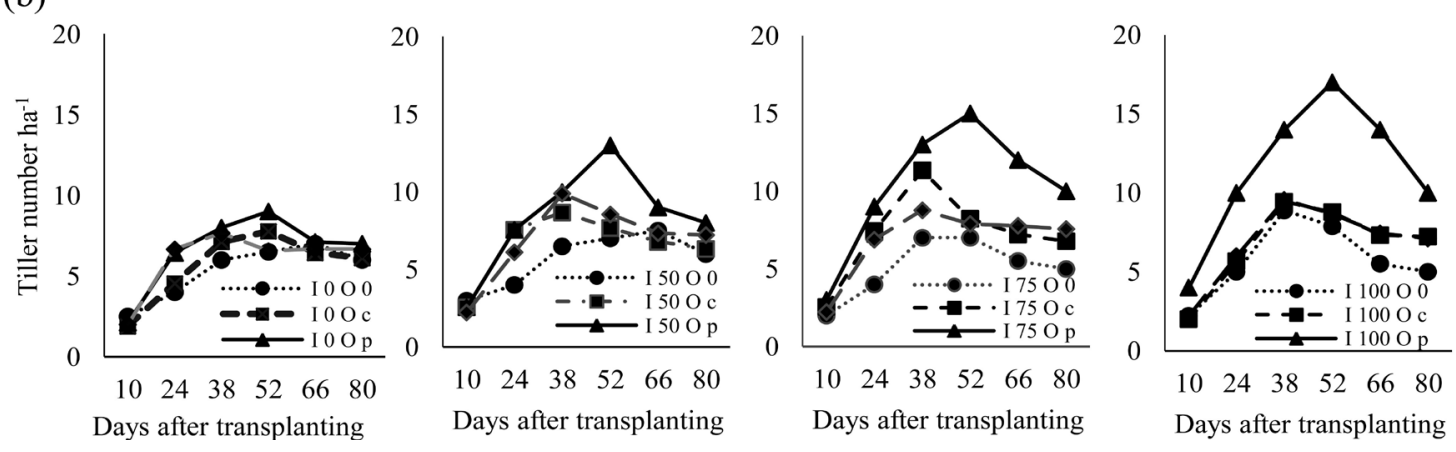

Figure 3. Tillering pattern of hybrid rice (Palethwe-1) as affected by combined application of organic manures and inorganic fertilizers in (a) dry season and (b) wet season, 2015. The numbers followed by I show the percentage of NPK applied based on $150 \mathrm{~kg} \mathrm{~N} \mathrm{ha}^{-1}, 70 \mathrm{~kg} \mathrm{P}_{2} \mathrm{O}_{5} \mathrm{ha}^{-1}$ and $120 \mathrm{~kg} \mathrm{~K}_{2} \mathrm{O} \mathrm{ha}{ }^{-1}$. I = Inorganic fertilizer; $\mathrm{O}_{\mathrm{c}}=$ cow manure, $\mathrm{O}_{\mathrm{p}}=$ poultry manure and $\mathrm{O}_{\mathrm{v}}=$ vermicompost. 

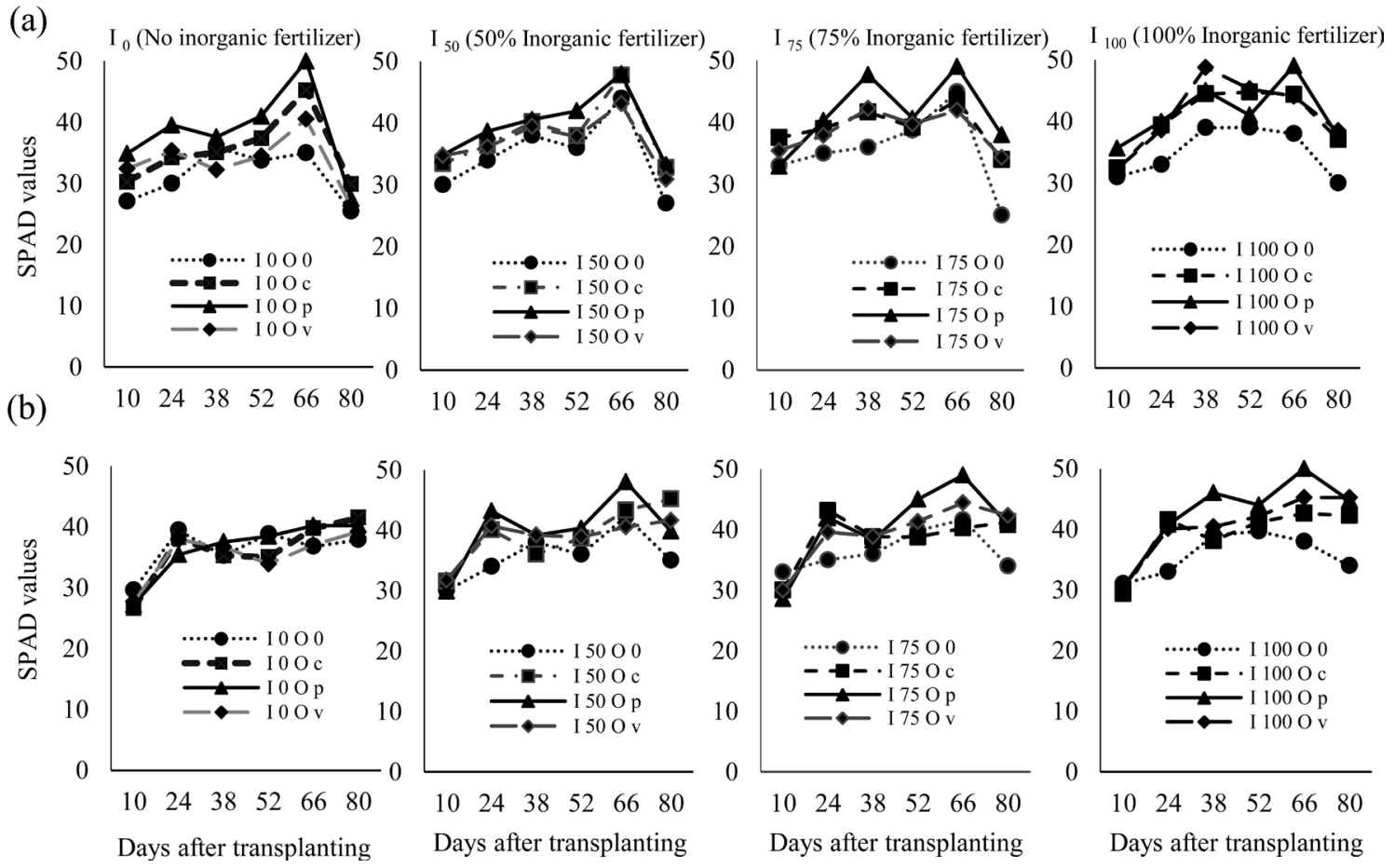

Figure 4. Changes in SPAD values of hybrid rice (Palethwe-1) as affected by combined application of organic manures and inorganic fertilizers in (a) dry season and (b) wet season, 2015. The numbers followed by I show the percentage of NPK applied based on $150 \mathrm{~kg} \mathrm{~N} \mathrm{ha}^{-1}, 70 \mathrm{~kg} \mathrm{P}_{2} \mathrm{O}_{5} \mathrm{ha}^{-1}$ and $120 \mathrm{~kg} \mathrm{~K}_{2} \mathrm{O} \mathrm{ha}{ }^{-1}$. I = Inorganic fertilizer; $\mathrm{O}_{c}$ = cow manure, $\mathrm{O}_{\mathrm{p}}=$ poultry manure and $\mathrm{O}_{\mathrm{v}}=$ vermicompost.

than those of the $\mathrm{O}_{0}$ plots. A similar pattern was observed during the wet season where the $\mathrm{O}_{\mathrm{p}}$ treatments also had a bigger effect on SPAD values than the other manures (Figure 4(b)). Without organic manure or inorganic fertilizers, optimum SPAD values could not be maintained and these were below 40 at all developmental stages throughout both seasons in the $\mathrm{I}_{0} \mathrm{O}_{0}$ treatment plots (Figure 4).

Significant differences in total dry matter accumulation (TDM) were recorded using different inorganic fertilizers throughout both seasons (Table 3). In the dry season, the $\mathrm{I}_{100}$ treatment provided the greatest TDM at the active tillering stage (24 DAT), while the plots with no NPK fertilizer $\left(\mathrm{I}_{0}\right)$ produced less TDM. After this developmental stage, differences were observed in the TDM using $\mathrm{I}_{50}$ treatments, but not between $\mathrm{I}_{75}$ and $\mathrm{I}_{100}$ treatments (Figure 5). During the wet season, significant differences in TDM produced by the different inorganic fertilizers were observed only at harvest time. However, the different organic manures significantly influenced TDM throughout both seasons. The $\mathrm{O}_{\mathrm{p}}$ combined with inorganic fertilizer treatments produced higher TDM compared with $\mathrm{O}_{v}$ and $\mathrm{O}_{c}$ treatments until the plants flowered. At harvest time, the highest TDM $\left(20 \mathrm{t} \cdot \mathrm{ha}^{-1}\right)$ was recorded in the $\mathrm{I}_{100} \mathrm{O}_{\mathrm{p}}$ fertilizer treatments and this was similar to values recorded using $\mathrm{I}_{100} \mathrm{O}_{c}\left(19 \mathrm{t} \cdot \mathrm{ha}^{-1}\right)$ during the dry season (Figure 5). TDM values for the different manure treatments combined with $\mathrm{I}_{75}$ did not differ significantly. Although it contained only half as much NPK, the $\mathrm{I}_{50} \mathrm{O}_{\mathrm{p}}$ treatment produced a similar TDM $\left(17.51 \mathrm{t} \cdot \mathrm{ha}^{-1}\right)$ to the $\mathrm{I}_{100} \mathrm{O}_{\mathrm{p}}$ treatment $\left(19.54 \mathrm{t} \cdot \mathrm{ha}^{-1}\right)$ 
Table 3. Probability values using ANOVA of dry matter accumulation ( $\mathrm{t} \cdot \mathrm{ha}^{-1}$ ) of hybrid rice (Palethwe-1) at the critical growth stages in both season (dry and wet season), 2015.

\begin{tabular}{|c|c|c|c|c|c|c|c|c|}
\hline \multirow{3}{*}{ Source } & \multicolumn{8}{|c|}{ Probability $\mathrm{P}$ value } \\
\hline & \multicolumn{4}{|c|}{ Dry season (2015) } & \multicolumn{4}{|c|}{ Wet season (2015) } \\
\hline & $\begin{array}{c}\text { Active tillering } \\
\text { stage }\end{array}$ & $\begin{array}{c}\text { Panicle } \\
\text { initiation stage }\end{array}$ & $\begin{array}{c}\text { Flowering } \\
\text { stage }\end{array}$ & Harvest & $\begin{array}{c}\text { Active tillering } \\
\text { stage }\end{array}$ & $\begin{array}{c}\text { Panicle initiation } \\
\text { stage }\end{array}$ & $\begin{array}{c}\text { Flowering } \\
\text { stage }\end{array}$ & Harvest \\
\hline Inorganic fertilizer (I) & $<0.0001$ & 0.0243 & 0.0175 & $<0.0001$ & 0.0011 & 0.0001 & $<0.0001$ & $<0.0001$ \\
\hline Organic manures $(\mathrm{O})$ & $<0.0001$ & $<0.0001$ & $<0.0001$ & $<0.0001$ & 0.0244 & 0.0026 & 0.0026 & $<0.0001$ \\
\hline $\mathrm{I} \times \mathrm{O}$ & 0.0013 & ns & ns & 0.0015 & ns & ns & ns & 0.0220 \\
\hline CV \% & 9.43 & 12.41 & 16.73 & 7.18 & 19.82 & 13.66 & 13.54 & 6.91 \\
\hline
\end{tabular}

ns = non-significant difference.

At active tillering stage

At panicle initiation stage

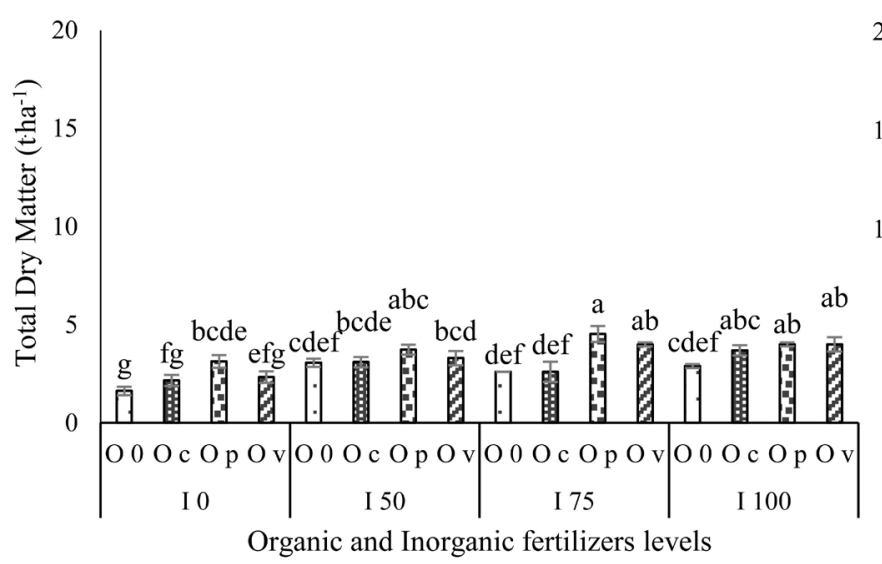

At flowering stage

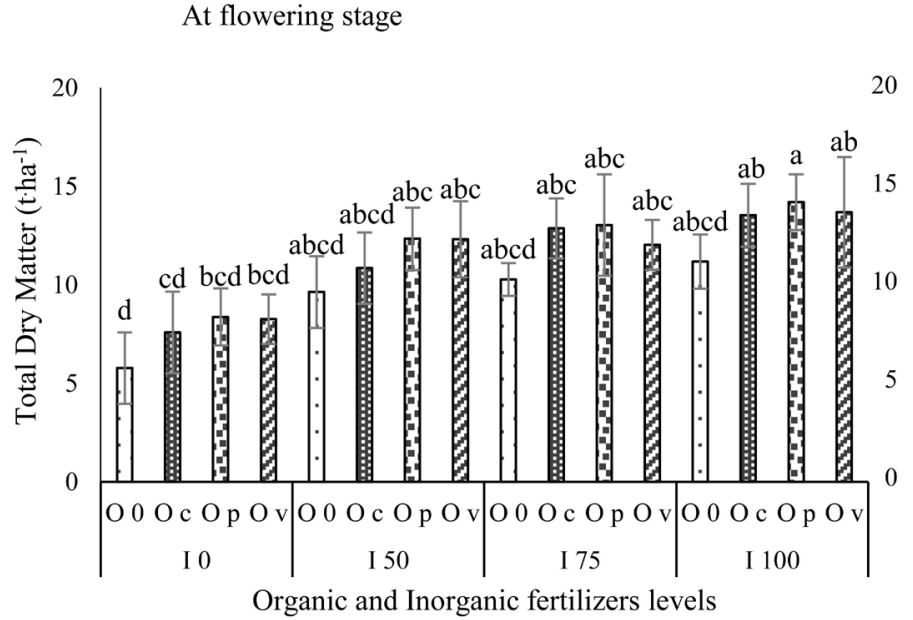

At harvest

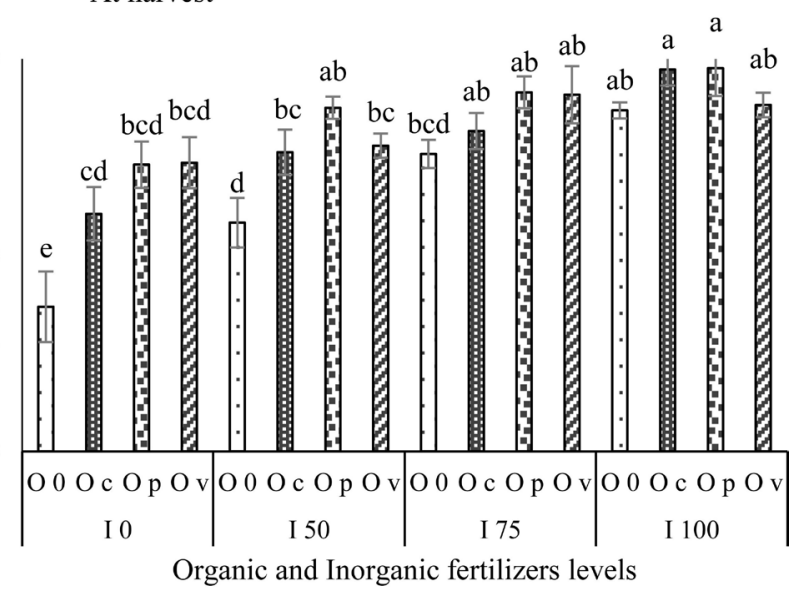

Figure 5. Dry matter accumulation ( $\mathrm{t} \cdot \mathrm{ha}^{-1}$ ) of hybrid rice (Palethwe-1) as affected by combined application of organic manures and inorganic fertilizers at the critical growth stages in dry season, 2015. The histograms with the same letter are not significantly different by the Tukey HSD test $(\mathrm{p}<0.05)$. The bar on each histogram indicates standard deviation. The numbers followed by I show the percentage of NPK applied based on $150 \mathrm{~kg} \mathrm{~N} \mathrm{ha}^{-1}, 70 \mathrm{~kg} \mathrm{P}_{2} \mathrm{O}_{5} \mathrm{ha}^{-1}$ and $120 \mathrm{~kg} \mathrm{~K}_{2} \mathrm{O} \mathrm{ha}^{-1}$. I $=$ Inorganic fertilizer; $\mathrm{O}_{\mathrm{c}}=$ cow manure, $\mathrm{O}_{\mathrm{p}}=$ poultry manure and $\mathrm{O}_{\mathrm{v}}=$ vermicompost.

(Figure 5). Similar results were observed during the wet season (Figure 6). Combining $\mathrm{I}_{50}$ with $\mathrm{O}_{\mathrm{p}}\left(16.18 \mathrm{t} \cdot \mathrm{ha}^{-1}\right)$ and $\mathrm{O}_{\mathrm{v}}\left(16.07 \mathrm{t} \cdot \mathrm{ha}^{-1}\right)$ produced TDM simi- 


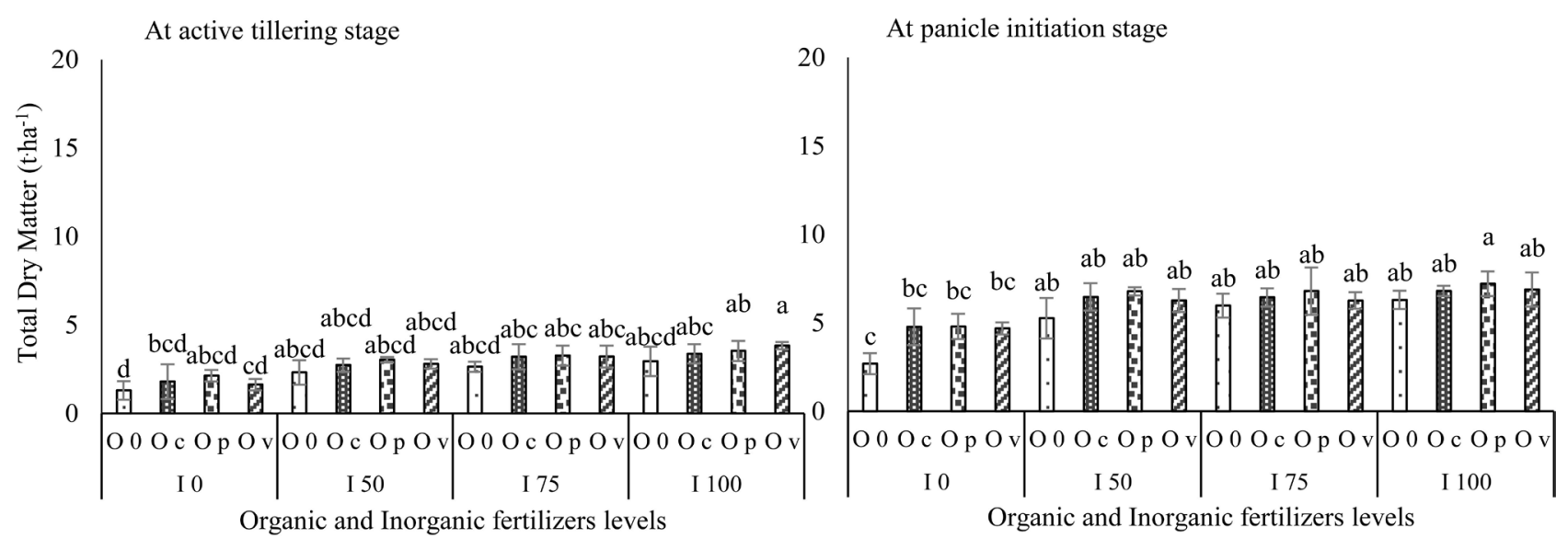

lar to that produced by other combinations of organic manures with $\mathrm{I}_{100}\left[\mathrm{I}_{100} \mathrm{O}_{c}\right.$ $\left(18.36 \mathrm{t} \cdot \mathrm{ha}^{-1}\right), \mathrm{I}_{100} \mathrm{O}_{\mathrm{p}}\left(18.03 \mathrm{t} \cdot \mathrm{ha}^{-1}\right)$, and $\mathrm{I}_{100} \mathrm{O}_{\mathrm{v}}\left(18.47 \mathrm{t} \cdot \mathrm{ha}^{-1}\right)$ ]. The lowest TDM was recorded in $\mathrm{I}_{0} \mathrm{O}_{0}$ plots $\left(5.3 \mathrm{t} \cdot \mathrm{ha}^{-1}\right.$ and $\left.6.1 \mathrm{t} \cdot \mathrm{ha}^{-1}\right)$ in both seasons (Figure 5 and Figure 6).

\subsection{Harvest Index, Yield, and Yield Parameters}

The harvest index (HI) ranged from 0.42 to 0.56 for both inorganic fertilizer and organic manure treatments and there were significant differences among them. However, similar $\mathrm{HI}$ values were measured among $\mathrm{I}_{50}, \mathrm{I}_{75}$, and $\mathrm{I}_{100}$ treatments throughout both seasons. For the organic manures, the $\mathrm{O}_{\mathrm{p}}$ treatment produced the highest HI values. These were 0.54 and 0.51 in the dry and wet seasons, respectively. The lowest $\mathrm{HI}$ values were recorded for the $\mathrm{I}_{0} \mathrm{O}_{0}$ treatment (Table 4 and Table 5).

The number of panicles hill ${ }^{-1}$ was significantly affected by different inorganic fertilizer and organic manure treatments in both seasons. The $\mathrm{I}_{100}$ plots produced the highest mean panicle number (11.47) and this was similar to that produced At panicle initiation stage
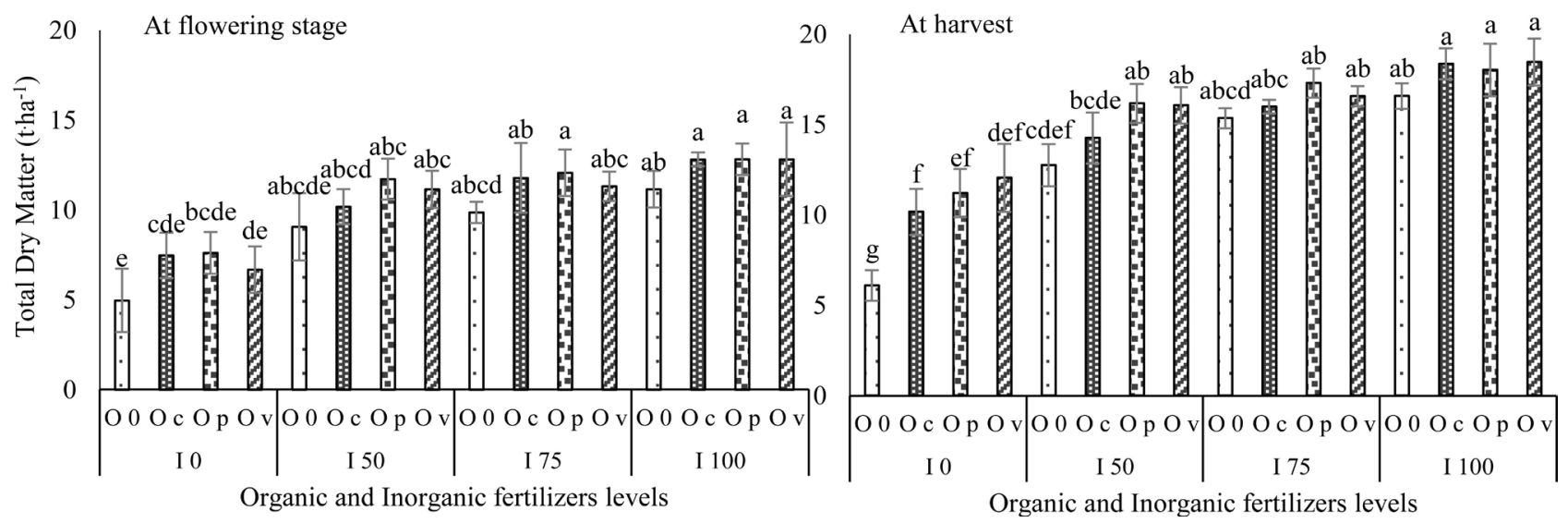

Figure 6. Dry matter accumulation ( $\mathrm{t} \cdot \mathrm{ha}^{-1}$ ) of hybrid rice (Palethwe-1) as affected by combined application of organic manures and inorganic fertilizers at the critical growth stages in wet season, 2015. The histograms with the same letter are not significantly different by the Tukey HSD test $(\mathrm{p}<0.05)$. The bar on each histogram indicates standard deviation. The numbers followed by $\mathrm{I}$ show the percentage of NPK applied based on $150 \mathrm{~kg} \mathrm{~N} \mathrm{ha}^{-1}, 70 \mathrm{~kg} \mathrm{P}_{2} \mathrm{O}_{5} \mathrm{ha}^{-1}$ and $120 \mathrm{~kg} \mathrm{~K}_{2} \mathrm{O} \mathrm{ha}^{-1}$. I = Inorganic fertilizer; $\mathrm{O}_{c}=$ cow manure, $\mathrm{O}_{\mathrm{p}}=$ poultry manure and $\mathrm{O}_{\mathrm{v}}=$ vermicompost. 
Table 4. Yield, yield components and harvest index of hybrid rice (Palethwe-1) affected by organic manures and inorganic fertilizer levels in dry season, 2015.

\begin{tabular}{|c|c|c|c|c|c|c|c|}
\hline Treatment & $\begin{array}{l}\text { Yield } \\
\left(\mathrm{t} \cdot \mathrm{ha}^{-1}\right)\end{array}$ & $\begin{array}{l}\text { No. panicle } \\
\text { hill }^{-1}\end{array}$ & $\begin{array}{l}\text { No. spikelets } \\
\text { panicle }^{-1}\end{array}$ & $\begin{array}{l}\text { Filled } \\
\text { grain } \%\end{array}$ & $\begin{array}{l}1000 \text { grain } \\
\text { weight }(\mathrm{g})\end{array}$ & $\begin{array}{c}\text { Panicle } \\
\text { length }(\mathrm{cm})\end{array}$ & $\begin{array}{c}\text { Harvest } \\
\text { index }\end{array}$ \\
\hline \multicolumn{8}{|l|}{ Inorganic fertilizers (I) } \\
\hline $\mathrm{I}_{0}(0 \% \mathrm{NPK})$ & $4.26 \mathrm{c}$ & $7.03 \mathrm{c}$ & $112.63 \mathrm{c}$ & $72.86 \mathrm{~b}$ & $27.18 \mathrm{~b}$ & $22.75 \mathrm{~b}$ & $0.42 \mathrm{~b}$ \\
\hline $\mathrm{I}_{50}(50 \% \mathrm{NPK})$ & $8.13 \mathrm{~b}$ & $9.14 \mathrm{~b}$ & $145.53 \mathrm{~b}$ & $90.24 \mathrm{a}$ & $28.33 \mathrm{a}$ & $24.19 \mathrm{a}$ & $0.53 \mathrm{a}$ \\
\hline $\mathrm{I}_{75}(75 \% \mathrm{NPK})$ & $9.55 \mathrm{a}$ & $11.32 \mathrm{a}$ & $147.97 \mathrm{~b}$ & $89.96 \mathrm{a}$ & $28.51 \mathrm{a}$ & $24.36 \mathrm{a}$ & $0.55 \mathrm{a}$ \\
\hline $\mathrm{I}_{100}(100 \% \mathrm{NPK})$ & $9.56 \mathrm{a}$ & $11.47 \mathrm{a}$ & $154.39 \mathrm{a}$ & $91.62 \mathrm{a}$ & $28.72 \mathrm{a}$ & $24.49 \mathrm{a}$ & $0.56 \mathrm{a}$ \\
\hline Tukey $\mathrm{HSD}_{0.05}$ & 0.64 & 0.59 & 3.79 & 1.96 & 0.79 & 0.46 & 0.04 \\
\hline \multicolumn{8}{|l|}{ Organic manures $(\mathrm{O})$} \\
\hline $\mathrm{O}_{0}$ (omission) & $6.72 \mathrm{c}$ & $8.47 \mathrm{c}$ & $126.87 \mathrm{c}$ & $83.57 \mathrm{~b}$ & $27.79 \mathrm{a}$ & $23.39 \mathrm{c}$ & $0.48 \mathrm{~b}$ \\
\hline $\mathrm{O}_{\mathrm{c}}\left(5\right.$ ton $\left.\mathrm{ha}^{-1}\right)$ & $7.93 \mathrm{~b}$ & $10.02 \mathrm{~b}$ & $143.22 \mathrm{~b}$ & $86.93 \mathrm{a}$ & $28.34 \mathrm{a}$ & $24.04 \mathrm{ab}$ & $0.52 \mathrm{a}$ \\
\hline $\mathrm{O}_{\mathrm{p}}\left(5\right.$ ton $\left.\mathrm{ha}^{-1}\right)$ & $8.77 \mathrm{a}$ & $10.58 \mathrm{a}$ & $147.58 \mathrm{a}$ & $88.18 \mathrm{a}$ & $28.51 \mathrm{a}$ & $24.46 \mathrm{a}$ & $0.54 \mathrm{a}$ \\
\hline $\mathrm{O}_{\mathrm{v}}\left(5\right.$ ton $\left.\mathrm{ha}^{-1}\right)$ & $8.08 \mathrm{ab}$ & $9.89 \mathrm{~b}$ & $142.85 \mathrm{~b}$ & $87.02 \mathrm{a}$ & $28.09 \mathrm{a}$ & $23.91 \mathrm{ab}$ & $0.51 \mathrm{ab}$ \\
\hline Tukey $\mathrm{HSD}_{0.05}$ & 0.70 & 0.36 & 10.37 & 2.73 & 0.70 & 0.53 & 0.05 \\
\hline \multicolumn{8}{|l|}{$\operatorname{Pr}>F$} \\
\hline Inorganic fertilizers & $<0.001$ & $<0.001$ & $<0.001$ & $<0.001$ & 0.002 & $<0.001$ & $<0.001$ \\
\hline Organic manures & $<0.001$ & $<0.001$ & $<0.001$ & $<0.001$ & ns & 0.004 & 0.032 \\
\hline $\mathrm{I} \times \mathrm{O}$ & 0.004 & 0.007 & $<0.001$ & 0.003 & ns & ns & ns \\
\hline CV\% (a) & 5.78 & 4.31 & 6.33 & 3.10 & 2.01 & 1.94 & 8.38 \\
\hline CV\% (b) & 7.90 & 3.30 & 7.39 & 3.62 & 2.67 & 2.63 & 10.39 \\
\hline
\end{tabular}

In each column, means having a common letter are not significantly different at $5 \%$ level. The numbers followed by I show the percentage of NPK applied based on $150 \mathrm{~kg} \mathrm{~N} \mathrm{ha}^{-1}, 70 \mathrm{~kg} \mathrm{P}_{2} \mathrm{O}_{5} \mathrm{ha}^{-1}$ and $120 \mathrm{~kg} \mathrm{~K}_{2} \mathrm{O} \mathrm{ha}^{-1}$. I = Inorganic fertilizer; $\mathrm{O}_{\mathrm{c}}=$ cow manure, $\mathrm{O}_{\mathrm{p}}=$ poultry manure and $\mathrm{O}_{\mathrm{v}}=$ vermicompost. ns $=$ non-significant difference.

Table 5. Yield, yield components and harvest index of hybrid rice (Palethwe-1) affected by organic manures and inorganic fertilizers levels in wet season, 2015.

\begin{tabular}{|c|c|c|c|c|c|c|c|}
\hline Treatment & $\begin{array}{l}\text { Yield } \\
\left(\mathrm{t} \cdot \mathrm{ha}^{-1}\right)\end{array}$ & $\begin{array}{c}\text { No. panicle } \\
\text { hill }^{-1}\end{array}$ & $\begin{array}{l}\text { No. spikelets } \\
\text { panicle }^{-1}\end{array}$ & $\begin{array}{c}\text { Filled } \\
\text { grain \% }\end{array}$ & $\begin{array}{l}1000 \text { grain } \\
\text { weight }(\mathrm{g})\end{array}$ & $\begin{array}{c}\text { Panicle } \\
\text { length }(\mathrm{cm})\end{array}$ & $\begin{array}{c}\text { Harvest } \\
\text { index }\end{array}$ \\
\hline \multicolumn{8}{|l|}{ Inorganic fertilizers (I) } \\
\hline $\mathrm{I}_{0}(0 \% \mathrm{NPK})$ & $5.17 \mathrm{~b}$ & $6.72 \mathrm{c}$ & $95.95 \mathrm{~b}$ & $75.39 \mathrm{~b}$ & $22.30 \mathrm{~b}$ & $21.84 \mathrm{~b}$ & $0.42 \mathrm{~b}$ \\
\hline $\mathrm{I}_{50}(50 \% \mathrm{NPK})$ & $8.15 \mathrm{a}$ & $7.67 \mathrm{~b}$ & $123.64 \mathrm{a}$ & $80.43 \mathrm{a}$ & $23.42 \mathrm{a}$ & $22.76 \mathrm{ab}$ & $0.50 \mathrm{ab}$ \\
\hline $\mathrm{I}_{75}(75 \% \mathrm{NPK})$ & $8.36 \mathrm{a}$ & $8.27 \mathrm{a}$ & $126.41 \mathrm{a}$ & 80.78 a & $23.51 \mathrm{a}$ & $22.90 \mathrm{a}$ & $0.51 \mathrm{a}$ \\
\hline $\mathrm{I}_{100}(100 \% \mathrm{NPK})$ & $8.46 \mathrm{a}$ & $8.35 \mathrm{a}$ & $126.14 \mathrm{a}$ & $81.04 \mathrm{a}$ & $23.71 \mathrm{a}$ & $23.22 \mathrm{a}$ & $0.52 \mathrm{a}$ \\
\hline Tukey $\mathrm{HSD}_{0.05}$ & 0.80 & 0.46 & 6.92 & 3.91 & 0.75 & 1.05 & 0.09 \\
\hline \multicolumn{8}{|l|}{ Organic manures $(\mathrm{O})$} \\
\hline $\mathrm{O}_{0}$ (omission) & $7.17 \mathrm{~b}$ & $7.34 \mathrm{~b}$ & $110.75 \mathrm{~b}$ & $77.33 \mathrm{~b}$ & $22.66 \mathrm{~b}$ & $22.43 \mathrm{~b}$ & $0.46 \mathrm{~b}$ \\
\hline $\mathrm{O}_{\mathrm{c}}\left(5\right.$ ton $\left.\mathrm{ha}^{-1}\right)$ & $7.66 \mathrm{ab}$ & $7.83 \mathrm{ab}$ & $116.19 \mathrm{ab}$ & $80.11 \mathrm{a}$ & $23.41 \mathrm{ab}$ & $22.62 \mathrm{ab}$ & $0.49 \mathrm{ab}$ \\
\hline $\mathrm{O}_{\mathrm{p}}\left(5\right.$ ton $\left.\mathrm{ha}^{-1}\right)$ & $7.78 \mathrm{a}$ & $8.20 \mathrm{a}$ & $125.99 \mathrm{a}$ & 80.67 a & $23.58 \mathrm{a}$ & $23.29 \mathrm{a}$ & $0.51 \mathrm{a}$ \\
\hline $\mathrm{O}_{\mathrm{v}}\left(5\right.$ ton $\left.\mathrm{ha}^{-1}\right)$ & $7.54 \mathrm{ab}$ & $7.60 \mathrm{ab}$ & $119.19 \mathrm{ab}$ & $79.53 \mathrm{a}$ & $23.27 \mathrm{ab}$ & $23.00 \mathrm{ab}$ & $0.49 \mathrm{ab}$ \\
\hline Tukey $\mathrm{HSD}_{0.05}$ & 0.55 & 0.60 & 9.23 & 2.73 & 0.91 & 0.79 & 0.04 \\
\hline \multicolumn{8}{|l|}{$\operatorname{Pr}>F$} \\
\hline Inorganic fertilizers & $<0.001$ & $<0.001$ & $<0.001$ & 0.007 & 0.002 & 0.077 & 0.024 \\
\hline Organic manures & 0.035 & 0.005 & 0.019 & 0.088 & 0.056 & 0.456 & 0.008 \\
\hline $\mathrm{I} \times \mathrm{O}$ & 0.997 & 0.982 & 0.994 & 0.997 & 1.000 & 1.000 & 0.984 \\
\hline CV\% (a) & 7.56 & 4.29 & 4.15 & 3.49 & 2.30 & 4.65 & 13.69 \\
\hline CV\% (b) & 6.54 & 6.92 & 9.29 & 4.08 & 3.50 & 3.91 & 7.42 \\
\hline
\end{tabular}

In each column, means having a common letter are not significantly different at $5 \%$ level. The numbers followed by I show the percentage of NPK applied based on $150 \mathrm{~kg} \mathrm{~N} \mathrm{ha}^{-1}, 70 \mathrm{~kg} \mathrm{P}_{2} \mathrm{O}_{5} \mathrm{ha}^{-1}$ and $120 \mathrm{~kg} \mathrm{~K}_{2} \mathrm{O} \mathrm{ha}{ }^{-1}$. I = Inorganic fertilizer; $\mathrm{O}_{\mathrm{c}}=$ cow manure, $\mathrm{O}_{\mathrm{p}}=$ poultry manure and $\mathrm{O}_{\mathrm{v}}=$ vermicompost. 
by the $\mathrm{I}_{75}$ plots (11.32). Fewer panicles were produced by $\mathrm{I}_{50}$ treatments compared with $\mathrm{I}_{75}$ and $\mathrm{I}_{100}$ treatments but fewer still were produced by $\mathrm{I}_{0}$ treatments. However, different inorganic fertilizer levels had no significant effect on the length of panicle, except $\mathrm{I}_{0}$ (control) (Table 4). Similar results were recorded for inorganic fertilizer treatments during the wet season (Table 5). Among the organic manures, the $\mathrm{O}_{\mathrm{p}}$ treatment produced the highest mean panicle numbers (10.58 and 8.2) and the highest panicle length $(24.46 \mathrm{~cm}$ and $23.29 \mathrm{~cm})$ in the dry and wet seasons, respectively, followed by the $\mathrm{O}_{c}$ and $\mathrm{O}_{\mathrm{v}}$ treatments.

The use of $I_{100}$ fertilizer significantly increased the number of spikelets per panicle, producing the highest values in both the wet (126.14) and dry (154.39) seasons. Similar numbers of spikelets were produced by $\mathrm{I}_{50}$ and $\mathrm{I}_{75}$ treatments during the wet season (Table 5). The fewest spikelets were produced by $\mathrm{I}_{0}$ treatments in both the dry (112.63) and wet (95.95) seasons. For the organic manures, the $\mathrm{O}_{\mathrm{p}}$ treatment produced the highest number of spikelets in both the dry (147.58) and wet (125.99) seasons, followed by the $\mathrm{O}_{c}$ and $\mathrm{O}_{v}$ treatments. Lower spikelet numbers were produced by $\mathrm{O}_{0}$ treatments in the dry (126.87) and wet (110.75) seasons due to severe deficiencies in $\mathrm{N}$ at the vegetative stage (Table 4 and Table 5).

The different inorganic fertilizer treatments produced significant differences in the percentage of filled grains. The highest filled grain percentage was produced by $\mathrm{I}_{100}$ treatments during the dry (91.62\%) and wet (81.04\%) seasons. Similar values were produced by $\mathrm{I}_{50}$ and $\mathrm{I}_{75}$ treatments, with the $\mathrm{I}_{0}$ treatment producing the lowest filled grain percentages in both seasons (Table 4 and Table $5)$. The $\mathrm{O}_{\mathrm{p}}$ treatment produced the highest filled grain percentage in both the dry (88.18\%) and wet (80.67\%) seasons but these values did not differ significantly from those recorded for the $\mathrm{O}_{c}$ and $\mathrm{O}_{v}$ treatments. The $\mathrm{O}_{0}$ treatment produced the lowest percentages in both season (Table 4 and Table 5).

Thousand grain weight was unaffected by the different inorganic fertilizer treatments in either season. However, the thousand grain weight produced by the $I_{0}$ treatment was significantly lower than that produced by $I_{50}, I_{75}$, and $I_{100}$ treatments. Although the different organic manure treatments did not have a significant effect on thousand grain weight, the $\mathrm{O}_{p}$ treatment produced the highest values in both the dry and wet seasons (Table 4 and Table 5). Conversely, panicle length was not significantly affected by the different inorganic fertilizer treatments. However, the $\mathrm{I}_{0}$ treatment produced the shortest panicles in both seasons. Although panicles of similar length were produced by different organic manure treatments, the $\mathrm{O}_{\mathrm{p}}$ treatment produced slightly longer panicles. Similar trends were observed during the wet season (Table 5).

Significant differences in yield were produced by the different inorganic fertilizers and organic manures in both seasons. The highest yields were produced by the $\mathrm{I}_{100}$ treatments $\left(9.56 \mathrm{t} \cdot \mathrm{ha}^{-1}\right.$ in the dry and $8.46 \mathrm{t} \cdot \mathrm{ha} \mathrm{a}^{-1}$ in the wet season) and these were similar to those produced by the $I_{75}$ treatments $\left(9.55 \mathrm{t} \cdot \mathrm{ha}^{-1}\right.$ in dry and $8.36 \mathrm{t} \cdot \mathrm{ha}^{-1}$ in the wet season). The $\mathrm{I}_{50}$ treatment plots produced lower yields but these were still higher than in the $\mathrm{I}_{0}$ plots. For the organic manures, the $\mathrm{O}_{\mathrm{p}}$ 
treatments produced the maximum yields in both the dry $\left(8.77 \mathrm{t} \cdot \mathrm{ha}^{-1}\right)$ and wet $\left(7.78 \mathrm{t}^{\mathrm{h}} \mathrm{h}^{-1}\right)$ seasons, followed by the $\mathrm{O}_{c}$ and $\mathrm{O}_{\mathrm{v}}$ treatments. Combining inorganic fertilizers and organic manures demonstrated that the $\mathrm{O}_{\mathrm{p}}$ plus $\mathrm{I}_{50}, \mathrm{I}_{75}$, and $\mathrm{I}_{100}$ treatments produced the highest yields $\left(9.78,10.17\right.$, and $10.27 \mathrm{t} \cdot \mathrm{ha}^{-1}$, respectively). However, there were no significant differences between these values in the dry season (Figure $7(a)$ ). Similar observations were made for the wet season (Figure $7(b))$. Organic manures alone $\left(\mathrm{O}_{0}\right)$ did not produce high yields in either season.

\section{Discussion}

Our analysis indicated that the soil used in these experiments was a sandy loam. Regular rice cultivation meant the soil $\mathrm{pH}$ was approximately neutral ( $\mathrm{pH}$ 6.6). It had a low capacity for cation-exchange $(8 \mathrm{cmol} / \mathrm{kg})$ and a low level of organic matter $(1.8 \%)$. There were moderate amounts of available $\mathrm{N}\left(73 \mathrm{mg} \cdot \mathrm{kg}^{-1}\right)$ and $\mathrm{P}$

(a)

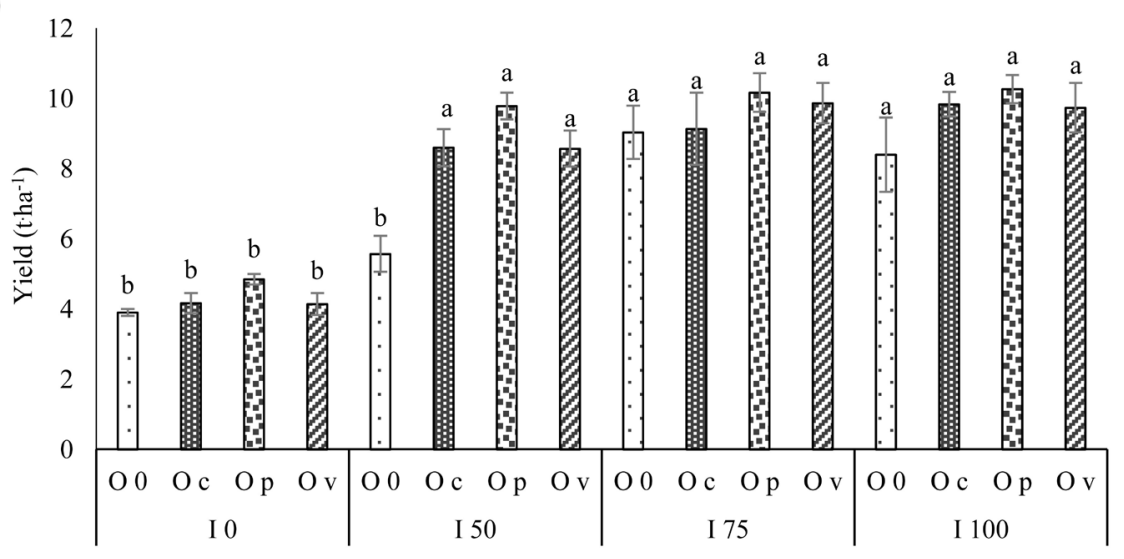

(b)

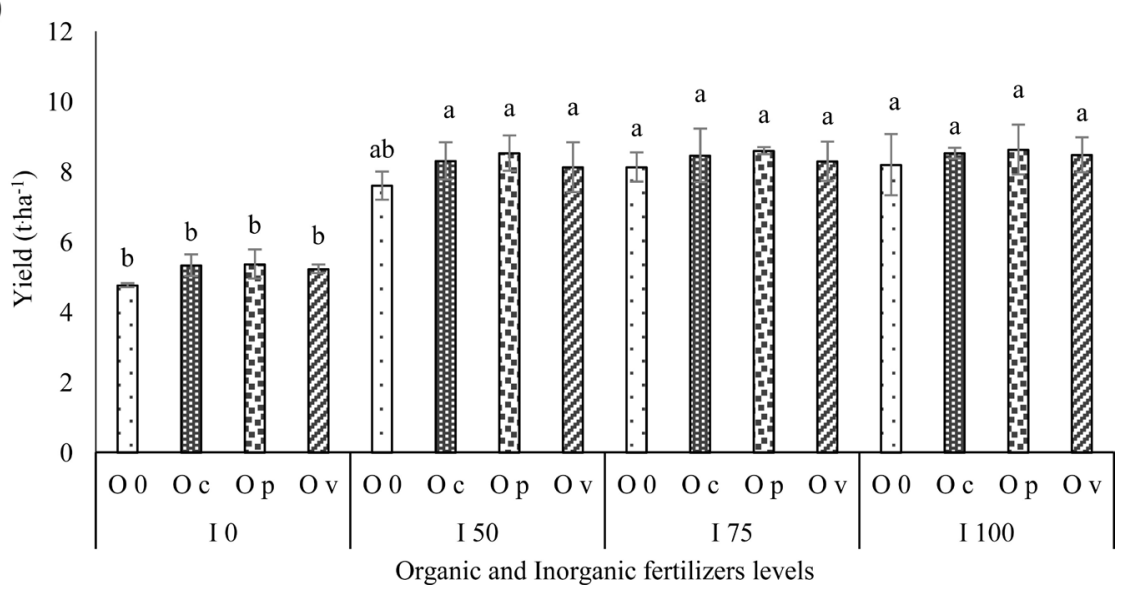

Figure 7. Yield (t.ha ${ }^{-1}$ ) of hybrid rice (Palethwe-1) as affected by combined application of organic manures and inorganic fertilizers in (a) dry season and (b) wet season, 2015. The histograms with the same letter are not significantly different by the Tukey HSD test $(\mathrm{p}<$ 0.05 ). The bar on each histogram indicates standard deviation. The numbers followed by I show the percentage of NPK applied based on $150 \mathrm{~kg} \mathrm{~N} \mathrm{ha}^{-1}, 70 \mathrm{~kg} \mathrm{P}_{2} \mathrm{O}_{5} \mathrm{ha}^{-1}$ and $120 \mathrm{~kg}$ $\mathrm{K}_{2} \mathrm{O} \mathrm{ha}^{-1}$. I = Inorganic fertilizer; $\mathrm{O}_{c}=$ cow manure, $\mathrm{O}_{\mathrm{p}}=$ poultry manure and $\mathrm{O}_{\mathrm{v}}=$ vermicompost. 
(20 $\left.\mathrm{mg} \cdot \mathrm{kg}^{-1}\right)$, but little available $\mathrm{K}\left(77 \mathrm{mg} \cdot \mathrm{kg}^{-1}\right)$. The soil data were evaluated using guidelines published by the Federal Ministry of Agriculture and Natural Resources [29].

This study was conducted in the central dry zone of Myanmar where sandy loam soils predominate in rice growing areas. The dry zone is characterized by clay, sandy loam, and sandy soils that also contain gravel. Hadden [30] observed that soil types found in the dry zone are not particularly fertile and have low quantities of organic matter. Potassium levels are too low to be ideal for agriculture. $\mathrm{N}$ is required for all non-legume crops regardless of soil type. In the dry zone of Myanmar, rice is cultivated as monsoon and summer rice every year and most farmers apply large amounts of inorganic fertilizers. Rice straw is used for animal feed and never returned to the rice field. Crucial soil components are constantly being depleted due to intensive farming and the extensive use of chemical fertilizers with little or no organic manure. The increasing intensity of land use has depleted soil nutrients. The only way to replenish organic matter in the short term is to apply it directly, for example in the form of manure [31]. The results of this study suggest that the quantities of chemical fertilizers used for hybrid rice cultivation in the dry zone of Myanmar could be significantly reduced and replaced by organic manures.

In this study, the maximum grain yield was produced using $\mathrm{I}_{100}$ treatments in both seasons. However, combining organic and inorganic fertilizers resulted in the $\mathrm{I}_{50} \mathrm{O}_{\mathrm{p}}$ treatment producing a similar yield to that produced by $\mathrm{I}_{100}$ treatments. The $\mathrm{I}_{50} \mathrm{O}_{c}$ and $\mathrm{I}_{50} \mathrm{O}_{\mathrm{v}}$ treatments also produced high yields. Our analysis demonstrated that $\mathrm{O}_{\mathrm{p}}$ had a higher nutrient content than either $\mathrm{O}_{c}$ or $\mathrm{O}_{v}$. Rajni and Srivastava [32] found that grain yield was significantly increased by combining organic manures and chemical fertilizers. However, the application of organic manures alone did not significantly enhance the yield of hybrid rice in either season. Akter et al. [33] also found that combining manure with chemical fertilizer treatments led to significantly higher yields and yield parameters than using chemical fertilizers alone. Therefore, it is clear that the combined application of organic manures and inorganic fertilizers is highly beneficial for sustainability in crop production [34].

Our analysis of yield components demonstrated that $\mathrm{O}_{\mathrm{p}}$ treatment had a significant effect on panicle number hill $^{-1}$, spikelet number panicle ${ }^{-1}$, filled grain (\%), and panicle length resulting in the maximum values for both seasons. Babu et al. [35] noted a significant increase in panicle length due to the application of organic manure and chemical fertilizers. However, the number of panicles was not significantly higher than that produced by $\mathrm{O}_{c}$ and $\mathrm{O}_{\mathrm{v}}$ treatments. In general, panicle number is strongly associated with tiller number. Chaturvedi [36] reported that a greater number of tillers, particularly fertile tillers, led to higher yields. At the tillering developmental stage, the maximum tiller number was produced by the $\mathrm{I}_{75} \mathrm{O}_{\mathrm{p}}$ treatment. However, a similar number of tillers were produced by $\mathrm{I}_{50} \mathrm{O}_{\mathrm{p}}$ and $\mathrm{I}_{100} \mathrm{O}_{\mathrm{p}}$ treatments. Eghball et al. [37], reported that the mineral content of $\mathrm{O}_{\mathrm{p}}$ is higher than that of $\mathrm{O}_{c}$ and $\mathrm{O}_{v}$ and that these minerals are 
more readily available to plants during early growth. Arif [38] also demonstrated that the maximum number of fertile tillers hill ${ }^{-1}$ was produced when $\mathrm{O}_{\mathrm{p}}$ was combined with $50 \%$ of the recommended amount of fertilizer. Apostol [39] reported that combining organic and inorganic fertilizers increased the production of panicles plant ${ }^{-1}$ in rice. Generally, tiller number during the wet season is lower than during the dry season, which might be due to inadequate sunlight essential for photosynthesis, during the wet season. Sun light levels are higher during the dry season and higher temperatures may also result in more tillers being produced [40].

A steady supply of nutrients at the panicle initiation and grain filling stages ensures that the maximum number of spikelets panicle ${ }^{-1}$ can be attained using $\mathrm{O}_{\mathrm{p}}$ treatment. Treatment using $\mathrm{O}_{c}$ and $\mathrm{O}_{\mathrm{v}}$ also results in a high number of spikelets panicle ${ }^{-1}$. Razzaque [41] also reported that spikelets panicle ${ }^{-1}$ increased significantly when organic manures and chemical fertilizers were combined. The maximum filled grain percentage was produced by $\mathrm{O}_{\mathrm{p}}$ treatment in both seasons. This is consistent with work by Kenchaiah [42], which demonstrated that $\mathrm{O}_{p}$ treatment produced better physical grain characteristics. The combined application of manures and fertilizers also significantly increases the number of filled grains panicle ${ }^{-1}[43]$. Thousand grain weight was unaffected by organic and inorganic fertilizer treatment types in either season. Islam et al. [44] reported that the thousand grain weight of rice was not significantly influenced by inorganic fertilizer levels because this depends mainly on genetic factors that are unique to each variety. Combining organic manures and inorganic fertilizers also increased panicle length compared with $\mathrm{I}_{0} \mathrm{O}_{0}$ treatment. Rahman [45] observed that applying organic manures together with chemical fertilizers increased panicle length. Supplying organic and inorganic fertilizers together increases the quantities of a variety of nutrients simultaneously and can reduce the amount of $\mathrm{N}$ lost by converting inorganic into organic $\mathrm{N}$ [46].

Myint et al. [47] suggested that the main advantage of using organic manures was to provide plants with nutrients that are released slowly throughout the growing season. Of all the manure types tested in this study, $\mathrm{O}_{\mathrm{p}}$ produced the highest SPAD values at all stages of development resulting in the greatest TDM. The maximum TDM was produced by the $\mathrm{I}_{100} \mathrm{O}_{\mathrm{P}}$ treatment but high TDM values were also obtained using $\mathrm{I}_{50} \mathrm{O}_{\mathrm{p}}$ and $\mathrm{I}_{75} \mathrm{O}_{\mathrm{p}}$ treatments in both seasons. Chaturvedi [36] reported that dry-matter accumulation in rice increased significantly in response to N-fertilizer application, at all stages of plant development. Treatment with $\mathrm{O}_{\mathrm{p}}$ was able to supply nutrients throughout the growth period. Treatment using $\mathrm{O}_{c}$ and $\mathrm{O}_{\mathrm{v}}$ was also effective in supporting plant growth. Eghball et al. [37] reported that $\mathrm{O}_{p}$ is richer in minerals than $\mathrm{O}_{c}$ and $\mathrm{O}_{v}$ throughout the first year after it is applied. In general, the SPAD values produced by all treatments gradually increased until $30 \mathrm{DAT}$ before decreasing, and this pattern may be linked to nutrient uptake in rice. SPAD values increased again to a maximum value (50) at approximately 66 DAT (flowering stage) in both seasons. Our results demonstrated that the lower leaf began to senesce and translocated $\mathrm{N}$ to the flag leaf, 
resulting in the flag leaf becoming greener. Turner and Jund [48] reported that the SPAD values of rice supplied with low quantities of $\mathrm{N}$ increased (to approximately 35) at the heading stage. Treatment using $\mathrm{I}_{50} \mathrm{O}_{\mathrm{p}}$ maintains stable SPAD values and has great potential for decreasing the quantities of chemical fertilizer used to grow hybrid rice. Liu et al. [49] also reported that the combined application of organic waste and chemical fertilizer was more effective than using either alone. This result was supported by Belay et al. [50] who demonstrated that treatment with $\mathrm{O}_{\mathrm{p}}$ combined with inorganic fertilizers enhances nutrient availability and creates suitable conditions for growth by reducing nutrient loss and increasing plant dry weight.

\section{Conclusion}

In this study, we demonstrated that the integrated application of organic manures and inorganic fertilizers was effective in enhancing growth, yield, and the yield components of hybrid rice. These results have the great potential for reducing the use of chemical fertilizers without decreasing the yield of hybrid rice. In the central dry zone of Myanmar, the $\mathrm{I}_{50}\left(75 \mathrm{~kg} \mathrm{~N} \mathrm{ha}^{-1}\right)+\mathrm{O}_{\mathrm{p}}\left(5 \mathrm{t} \cdot \mathrm{ha}^{-1}\right)$ treatment proved extremely good for cultivating hybrid rice. In regions where poultry are limited, $\mathrm{O}_{c}\left(5 \mathrm{t} \cdot \mathrm{ha}^{-1}\right)$ may also be used as an effective fertilizer in combination with $\mathrm{I}_{75}\left(112.5 \mathrm{~kg} \mathrm{~N} \mathrm{ha}^{-1}\right)$. In contrast, $\mathrm{O}_{\mathrm{v}}$ may be of limited use because of its low nutrient content and availability in Myanmar. Clearly, the combined application of organic manures and inorganic fertilizers can enhance soil $\mathrm{N}$ content for cultivating rice and improve both long term productivity [51] and ecological sustainability [52]. A major advantage of using organic wastes is that they can provide a variety of nutrients at low cost. Further studies investigating how different application methods and various types of organic and chemical fertilizers might enhance the growth of new rice varieties should be performed in the future.

\section{Acknowledgement}

This study was supported by Japanese Government (MEXT) Scholarship Program 2016-2019, Japan. We thank to Dr. Kyaw Kyaw Win (Professor) and Kumudra Win Mg (M. Agr. Sc), Department of Agronomy, Yezin Agricultural University, Myanmar for their contribution to this research.

\section{Conflict of Interest: Disclosure Statements}

I have disclosed that there are no conflicts of interest regarding publication of this article.

\section{References}

[1] IRRI (International Rice Research Institute) (2010) World Rice Statistics. International Rice Research Institute, Los Baños, Philippines. http://ricestat.irri.org/mistig/demos/php/global.php

[2] FAO (Food and Agricultural Organization) (2013) Statistical Year Book. Food and 
Agriculture Organization of the United Nations, Rome, 289 p.

[3] IRRI (International Rice Research Institute) (2016) Hybrid Rice. http://irri.org/news/hot-topics/hybrid-rice

[4] Duvick, D.N. (1999) Heterosis: Feeding People and Protecting Natural Resources. In: Coors, J.G. and Pandey, S., Eds., The Genetics and Exploitation of Heterosis in Crops, American Society of America, Madison, WI, 19-29.

[5] Grain (2005) Fiasco in the Field-An Update on Hybrid Rice in Asia. https://www.grain.org/article/entries/51-fiasco-in-the-field-an-update-on-hybrid-ri ce-in-asia

[6] Ramesh, S. and Chandrasekaran, B. (2007) Effect of Establishment Techniques and Nitrogen Management on the Leaf Nitrogen Concentration (LNC), Flowering, Nitrogen Use Efficiency and Quality of Rice Hybrid (Oryza sativa L.) ADTRH1. Agricultural Journal, 2, 38-45.

[7] Savci, S. (2012) An Agricultural Pollutant: Chemical Fertilizer. International Journal of Environmental Science and Development, 3, 73-80.

https://doi.org/10.7763/IJESD.2012.V3.191

[8] Antil, R.S. and Singh, M. (2007) Effects of Organic Manures and Fertilizers on Organic Matter and Nutrients Status of the Soil. Archives of Agronomy and Soil Science, 53, 519-528.

[9] Buresh, R.J. and Witt, C. (2008) Balancing Fertilizer Use and Profit in Asia's Irrigated Rice Systems. Better Crops, 92, 18-22.

[10] Bhuiyan, N.I. (1994) Crop Production Trends and Need of Sustainability in Agriculture. Paper Presented at the Workshop, Integrated Nutrient Management for Sustainable Agriculture held at SRDI, Dhaka Bangladesh in 26-28 June.

[11] Gupta, R.D. (2003) Effect of Poultry Manure with and without Chemical Fertilizers on Yield and Quality of BRRI DAHN29. Master Thesis, Department of Agricultural Chemistry, Bangladesh Agricultural University, Mymensingh, Bangladesh. http://www.saulibrary.edu.bd/daatj/public/index.php/thesis/thesis_individu $\underline{\mathrm{al} / 236}$

[12] Reddy, M.V. and Ohkura, K. (2004) Vermicomposting of Rice-Straw and Its Effects on Sorghum Growth. Journal of Tropical Ecology, 45, 327-331.

[13] Sunil, K., Rawat, C.R., Shiva, D. and Suchit, K.R. (2005) Dry Matter Accumulation, Nutrient Uptake and Changes in Soil Fertility Status as Influenced by Different Organic and Inorganic Sources of Nutrients to Forage Sorghum (Sorghum bicolor). Indian Journal of Agricultural Sciences, 75, 340-342.

[14] Domínguez, J. (2004) State-of-the-Art and New Perspectives on Vermicomposting Research. In: Edwards, C.A., Ed., Earthworm Ecology, CRC Press, Boca Raton, FL, 401-424. https://doi.org/10.1201/9781420039719.ch20

[15] Nambiar, K.K.M. (1991) Long-Term Fertility Effects on Wheat Productivity. In: Saunders, D.A., Ed., Wheat for the Non-Traditional Warm Areas, CIMMYT, 516521.

[16] Rayment, G.E. and Higginson, F.R. (1992) Australian Laboratory Handbook of Soil and Water Chemical Method. Reed International Books Australia P/L, Trading as Inkata Press, Port Melbourne, 330 p.

[17] Hussain, F. and Kauser, A.M. (1985) Evaluation of Alkaline Permanganate Method and Its Modification as an Index of Soil Nitrogen Availability. Plant and Soil, 84, 279-282. https://doi.org/10.1007/BF02143191

[18] Olsen, S.R., Cole, C.V., Watanabe, F.S. and Dean, L.A. (1954) Estimation of Available Phosphorus in Soil Extraction with Sodium Bicarbonate. USDA Circ. 939. U.S. 
Government Printing Office, Washington DC.

[19] Muramoto, J., Goto, I. and Ninaki. M. (1992) Rapid Analysis of Exchangeable Cations and Cation Exchange Capacity (CEC) of Soils by Shaking Extraction Method. Journal of Soil Science and Plant Nutrition, 63, 210-215.

[20] Kononova, M.M. (1966) Soil Organic Matter: Its Nature, Its Role in Soil Formation and in Soil Fertility. Pergamon Press Ltd., Oxford, 45-49.

[21] Liu, C.L., Wang, M.K. and Yang, C.C. (2001) Determination of Cation Exchange Capacity by One-Step Soil Leaching Column Method. Communications in Soil Science and Plant Analysis, 32, 2359-2372. https://doi.org/10.1081/CSS-120000378

[22] Nelson, D.W. and Sommers, L.E. (1996) Total Carbon, Organic Carbon, and Organic Matter. In: Sparks, D.L., et al., Eds., Methods of Soil Analysis. Part 3. Chemical Methods, SSSA Book Series No. 5, SSSA and ASA, Madison, WI, 961-1010.

[23] Kjeldahl, J. (1883) Neue Methode zur Bestimmung des Stickstoffs in organischen Körpern. Zeitschrift für Analytische Chemie, 22, 366-382. https://doi.org/10.1007/BF01338151

[24] Kitson, R.E. and Mellon, M.G. (1944) Colorimetric Determination of Phosphorous as Molybdivanadophosphoric Acid. Industrial and Engineering Chemistry, Analytical Edition, 16, 379-383. https://doi.org/10.1021/i560130a017

[25] Stevenson, A.E. and Langen, H.D. (1960) Measurement of Feed Intake by Grazing Cattle and Sheep VII. Modified Wet Digestion Method for Determination of Chromic Oxide in Feces. New Zealand Journal of Agricultural Research, 3, 314-319. https://doi.org/10.1080/00288233.1960.10418086

[26] Raghavan, R. (1991) A Rapid Turbidimetric Method for the Determination of Total Sulphur in Zinc Concentrate. Talanta, 38, 525-528.

[27] Walter, E. and Dean, J.R. (1974) Determination of Carbonate and Organic Matter in Calcareous Sediments and Sedimentary Rocks by Loss on Ignition: Comparison with Other Methods. Journal of Sedimentary Petrology, 44, 242-248.

[28] Yoshida, S. (1981) Fundamental of Rice Crop Science. International Rice Research Institute, Los Baños, Laguna, Philippines, 269.

[29] FPDD (1990) Literature Review on Soil Fertility Investigation in Nigeria. Federal Ministry of Agriculture and Natural Resources, Lagos, Nigeria, 5, 92-95.

[30] Hadden, R.L. (2008) The Geology of Burma (Myanmar): An Annotated Bibliography of Burma's Geology, Geography and Earth Science. Topographic Engineering Center, US Army Corps of Engineers, Alexandria, Virginia, 312 p. http://www.dtic.mil/cgi-bin/GetTRDoc?AD=ADA487552

[31] Glaser, B., Lehman, J., Fuhrboter, M., Solomon, D. and Zech, W. (2001) Carbon and Nitrogen Mineralization in Cultivated and Natural Savanna Soils of Northern Tanzania. Biology and Fertility of Soils, 33, 301-309. https://doi.org/10.1007/s003740000324

[32] Rajni, R., Srivastava, O.P. and Rani, R. (2001) Effect of Integration of Organics with Fertilizer N on Rice and N Uptake. Fertility News, 46, 63-65.

[33] Akter, M.S., Hasan, M.K.S., Adhikery, R.C. and Chowdhury, M.K. (1993) Integrated Management of Sesbania rostrata and Urea-Nitrogen in Rice under a Rice-Rice Cropping System. The Annals of Bangladesh Agriculture, 3, 114-189.

[34] Khan, A.R., Sarkar, S., Nanda, P. and Chandar, D. (2001) Organic Manuring through Gliricidia maculata for Rice Production. International Centre for Theoretical Physics (UNESCO and IAEA), Trieste, Italy Int. Rep. IC/IR/2001, 10, 1-4.

[35] Babu, S., Marimuthu, R., Manivanna, V. and Ramesh-Kumer, S. (2001) Effect of Organic and Inorganic Manures on Growth and Yield of Rice. Agricultural Science Di- 
gest, 21, 232-234.

[36] Chaturvedi, I. (2005) Effect of Nitrogen Fertilizers on Growth, Yield and Quality of Hybrid Rice (Oryza sativa L.). Journal of Central European Agriculture, 6, 611-618.

[37] Eghball, B., Wienhold, B.J., Gilley, J.E. and Eigenberg, R.A. (2002) Mineralization of Manure Nutrients. Journal of Soil and Water Conservation, 57, 470-473.

[38] Arif, M., Tasneem, M., Bashir, F., Yassen, G. and Iqbal, R.M. (2014) Effect of Integrated Use of Organic Manures and Inorganic Fertilizers on Yield and Yield Components of Rice. Journal of Agricultural Research, 52, 197-206.

[39] Apostol, E.D.F. (1989) Influence of Mirasoil Organic and X-Rice Liquid Fertilizer in Combination with Inorganic Fertilizer on IR66 and IR12 Rice Varieties. Malabeu, Metro Manila, Philippines.

http://agris.fao.org/agris-search/search.do?recordID=PH9010085

[40] Yoshida, S. (1973) Effects of Temperature on Growth of the Rice Plant (Oryza sativa L.) in a Controlled Environment. Soil Science and Plant Nutrition, 19, 299-310. https://doi.org/10.1080/00380768.1973.10432599

[41] Razzaque, M.M.A. (1996) Comparative Study on the Effect of Rice Straw, Farmyard Manure and Fertilizer Nitrogen on the Growth and Yields of BR11 Rice. MSc Thesis, Department of Soil Science, BAU, Mymensingh.

[42] Kenchaiah, A. (1997) Organic Farming in Rice. PhD Thesis, Tamil Nadu Agricultural University, Coimbatore.

[43] Satyanarayana, V., Prasead, P.V.V., Murthy, V.R.K. and Rodty, K.J. (2002) Influence of Combined Application of Farm Yard Manure and Inorganic Fertilizers on Yield Components of Irrigated Lowland Rice. Journal of Plant Nutrition, 25, 2081 2090.

[44] Islam, M.S., Akhter, M.M., Rahman, M.S.Q., Banu, M.B. and Khalequzzaman, K.M. (2008) Effect of Nitrogen and Number of Seedlings per Hill on the Yield and Yield Components of T. aman Rice (BRRI Dhan 33). International Journal of Sustainable Crop Production, 3, 61-65.

[45] Rahman, S. (1991) Influence of Organic Matter on the Yield and Mineral Nutrition of Modern Rice and Soil Properties. Bangladesh Rice Journal, 2, 107-112.

[46] Kramer, A.W., Doane, T.A., Horwath, W.R. and Kessel, C.V. (2002) Combining Fertilizer and Inorganic Inputs to Synchronize N Supply in Alternative Cropping Systems in California. Agriculture, Ecosystems \& Environment, 91, 233-243.

[47] Myint, A.K., Yamakawa, T., Zenmyo, T., Thao, H.T.B. and Sarr, P.S. (2011) Effects of Organic Manure Application on Growth, Grain Yield, and Nitrogen, Phosphorus, and Potassium Recoveries of Rice Variety Manawthuka in Paddy Soils of Differing Fertility. Communications in Soil Science and Plant Analysis, 42, 457-474. https://doi.org/10.1080/00103624.2011.542223

[48] Turner, F.T. and Jund, M.F. (1994) Assessing the Nitrogen Requirements of Rice Crops with a Chlorophyll Meter. Australian Journal of Experimental Agriculture, 34, 1001-1005. https://doi.org/10.1071/EA9941001

[49] Liu, J.R., Zhang, D.Y. and Zhou, W. (1990) The Effect of Mixed Application of Organic and Inorganic Fertilizers to Paddy Soil (The Third Report). Acta Agriculturae Universitis Jiangxiensis, 12, 37-42.

[50] Belay, A., Classens, A.S., Wehner, F.C. and De, B.J.M. (2001) Influence of Residual Manure on Selected Nutrient Elements and Microbial Composition of Soil under Long-Term Crop Rotation. South African Journal of Plant and Soil, 18, 1-6. https://doi.org/10.1080/02571862.2001.10634392

[51] Gill, H.S. and Meelu, O.P. (1982) Studies on the Substitution of Inorganic Fertilizers 
with Organic Manures and Their Effect on Soil Fertility in Rice Wheat Rotation. Fertilizer Research, 3, 303-313. https://doi.org/10.1007/BF01048935

[52] Zia, M.S., Munsif, M., Aslam, M. and Gill, A. (1992) Integrated Use of Organic Manures and Inorganic Fertilizers for the Cultivation of Lowland Rice in Pakistan. Soil Science and Plant Nutrition, 38, 331-338.

https://doi.org/10.1080/00380768.1992.10416497

\section{Scientific Research Publishing}

Submit or recommend next manuscript to SCIRP and we will provide best service for you:

Accepting pre-submission inquiries through Email, Facebook, LinkedIn, Twitter, etc. A wide selection of journals (inclusive of 9 subjects, more than 200 journals)

Providing 24-hour high-quality service

User-friendly online submission system

Fair and swift peer-review system

Efficient typesetting and proofreading procedure

Display of the result of downloads and visits, as well as the number of cited articles Maximum dissemination of your research work

Submit your manuscript at: http://papersubmission.scirp.org/

Or contact ajps@scirp.org 